\title{
Distribution and abundance of Zooplankton along Chitrapur, South-west coast of India
}

\author{
Mridula Rajesh, V. Moorthy and H.R.V. Reddy
}

Article Chronicle:

Received:

15.06.2018;

Revised :

12.11.2018;

Accepted :

25.11.2018

Key Words : Zooplankton, Abundance, Mangaluru, Species diversity, West coast
ABSTRACT : The present study was carried out over a period of 8 months from Oct. 2012 to May 2013 at 3 different depth contours viz., $4 \mathrm{~m}$ (St. 1), 8m (St. 2) and 12m (St. 3) along the coastal waters of Chitrapur, Mangaluru where Boulique Aniline Soda Factory (BASF) and Mangalore Refineries and Petro Chemical Limited (MRPL) discharge their effluents. In general, the zooplankton density was at its peak in the month of October and January and lower in the months of December and March/April. Copepodites formed the bulk of the total zooplankton and in the present investigation, they varied from 2,800 to $2,62,000 \mathrm{nos} / \mathrm{m}^{3}$. These contributed to 29.86 per cent, 28.57 per cent and 20.24 per cent of the total zooplankton population in St. 1, 2 and 3, respectively. The other zooplankton groups noticed were copepodites, chaetognaths, medusae, siphonophores, ctenophores, tintinids, cladocerans, lucifer, polychaetes, Protochordates and larvae of decapods, echinoderms, bivalves followed by fish eggs and larvae.The species diversity, richness and evenness were high during premonsoon season followed by postmonsoon season at all the stations.

HOW TO CITE THIS ARTICLE : Rajesh, Mridula, Moorthy, V. and Reddy, H.R.V. (2018). Distribution and abundance of Zooplankton along Chitrapur, South-west coast of India. Asian J. Environ. Sci., 13(1\&2): 17-22, DOI: 10.15740/HAS/AJES/13.1and2/17-22. Copyright@ 2018: Hind Agri-Horticultural Society.
Author for correspondence :

Mridula Rajesh

Department of Fisheries

Resources and

Management, College of

Fisheries, Mangalore

(Karnataka) India

Email : mridularajesh789

@ yahoo.co.in

See end of the article for

Coopted authors' 